\title{
Det ene og de mange
}

\section{Noter fra den amerikanske undergrund: Ishmael Reed, karnevallet og grotesken}

\author{
IB JOHANSEN
}

\section{Introduktion}

Ifølge idehistorikeren Arthur 0. Lovejoy i hans klassiske studie The Great Chain af Being $(1936,1960)$ er der to platoniske traditioner, som har domineret den vestlige tænkning fra antikken og op til nyere tid: en tradition som lægger vægt på det Ene som altings ophav (en fremhævelse af enhedsprincippet) (1) og en tradition som tværtimod fremhæver verdens og dens skabningers mangfoldighed (2). Lovejoy sætter det filosofiske tema (og det filosofiske problem) på spidsen, forsåvidt som det tidløse og ulegem.lige "Ene" (med hans ord) bliver til "den logiske grund såvel som den dynamiske kilde til eksistensen af et tidsligt og materielt og yderst mangfoldigt og varieret univers."1 I den vestlige kultur har begribeligvis både den jødiske og den kristne monoteisme først og fremmest understreget enhedsprincippet, med fremhævelsen af den ene sande kirke som hjemstedet for alle troende, med bekendelsen til en gud, etc., etc. (den kristne treenighedslære udgør i den sammenhæng et særligt teologisk problem, som i oldkirken gav anledning til. talløse dogmatiske stridigheder, men det er en anden historie). Hos William Blake spidsformuleres det omtalte kristne (monoteistiske) enhedsprincip med forbil-. ledlig klarhed og ironisk emfase i hans profeti The [First] Book af Urizen (1794), hvor alt hvad der bliver tilbage i en rigoristisk lovog-orden-verden er "Et bud, en glæde, et begær, / En forbandelse, en vægt, et mål, / En Konge, en Gud, en Lov" (,,One com.mand, one joy, one desire, / One curse, one weight, one measure, / One King, one God, one Law"). ${ }^{2}$ 
På trods af at U.S.A i allerhøjeste grad er et multietnisk og multikulturelt samfund har monoteismen alligevel i en eller anden form været dominerende siden kolonitiden Gf de første puritanske settlements, m.v.); men samtidig er det klart at den amerikanske "smeltedigel" (,melting-pot") derudover har haft plads til talrige afvigelser fra (netop) den monoteistiske norm. Her tænker jeg ikke blot på de mange subkulturer, som opstod på det nordamerikanske fastland i nittenhalvtredserne og -tresserne (f.eks. beat-kulturen, hippie- ogfl-ower power-bevægelsen, forskellige kulturelle strømihger forbundet med rockmusikken, stofkulturen i bred forstand og de politiske mindretals- og protestbevægelser i denne periode). Ifølge Mikhail Bakhtin er det i al almindelighed karakteristisk for hvad han beskriver som en folkelig karnevalskultur - og for dens litterære manifestationsformer - at den de-konstruerer en hvilkensomhelst enhedskulturs totalitoere prætentioner, et hvilketsomhelst forsøg på at etablere strengt hierarkisk opbyggede sociale helheder eller et lov-ogorden regimente. Som Bakhtin formulerer det i forbindelse med en gennemgang af den menippoiske satires genrekarakteristika: "Drømme, dagdrømme og sindssyge ødelægger den episke og tragiske helhed som en person og hans skæbne. [sædvanligvis] repræsenterer: de muligheder som er forbundet med en anden person og et andet liv kommer til syne i ham, han mister sine formålsbestemte kendetegn ['his finalized quc!lity'] og ophører med kun at betyde en ting; han ophører med at stemme overens med sig selv;. "3 Dvs. de karnivalistiske genrer repræsenterer et radikalt brud med en hvilkensomhelst monolitisk enhedstonkning.

Det har i høj grad relevans at tale om kamevalskulturen og dens litterære efterslæt i forbindelse med en undersøgelse som den foreliggende med fokus på den afro-amerikanske forfatter Ishmael Reeds forfatterskab. Reed er født i 1938 og debuterede i tresserne med den apokal $\mathrm{y}_{\mathrm{p}}$ tiske groteske The Freelance Pallbearers (1967), hvor den sorte antihelt Bukka Doopeyduk gennemløber en karriere, som ender med at han bliver "ophængt i kødkroge i Kejser Franz Josef-parken" (!), ${ }^{4}$ dis. selve plotstrukturen i Reeds roman kan læses som en parodisk version af Kristi lidelseshistorie, en sort-humoristisk eller "karnevaliseret" imitatio 
Christi. Overalt i sit forfatterskab trækker Ishmael Reed i det hele taget på folke- og populærkulturen og dens forskellige genrer (melodramaet, anekdoten, skrønen, avisnotitsen, the dime novel, krimien, sagn- og legendestof a f enhver art, etc., etc.). Og det er karakteristisk for hele Reeds narrative strategi, at hø;kulturen og dens frembringelser hos ham netop optræder i forskellige hybridformer og overalt kombineres med det føromtalte folke- og populærkulturelle materiale, uden at Reed i den forbindelse udviser nogensomhelst respekt for etablerede genre- og stilhierarkier inden for den litterære institution.

Ishmael Reed kommer i sin essaysamling Shrovetide in Old New Orleans $(1978,1989)$ mere direkte ind på kamevalskulturen i en af dens særlige amerikanske udformninger, d.v.s. i forbindelse med en kommentar til de festligheder der finder sted i New Orleans omkring den såkaldte Mardi Gras:

Mardi Gras er polyteistisk, ligesom Voudoun [d.v.s. voodoo] er det; den involverer trommer og dans som i Voudoun; begge "religioner" indbefatter rituelle masker og forklædninger. Hedenske og kristne riter blandes med hinanden. Mardi Gras betyder "Fede Tirsdag" på fransk, den tirsdag der går forud for aske-onsdag. På Mardi Gras er der en kaptajn som iscenesætter ceremonier for hvert enkelt "kompagni" [,krewe"] eller hver enkelt organisation eller kult...

Både Mardi Gras og Voudoun indbefatter hemmelige selskaber udstyret med flag, sange og andre ritualer, som er enestående for hvert enkelt af dem...s

Reed henviser ligeledes til et gadeoptog i New Orleans, hvis tema var "The Demon Actors in Milton's Paradise Lost", og denne spektakulære parade var (ifølge Reed) helt i voodoo-kultens ånd, „eftersom Milton placerer Afrikas guder i helvede."6

I de ovenanførte passager bemærker vi især den implicitte kritik af monoteismen som Reed her, som iøvrigt mange andre steder, på en karakteristisk underspillet maner tematiserer (i andre sammenhænge foregår det dog på en mere direkte måde); djævlerierne er samtidig i bedste overensstemmelse med kamevalskulturens hævdvundne ceremonielle former og festskikke, sådan som de f.eks. bliver beskrevet hos Mikhail Bakhtin (også Bakhtin kommenterer iøvrigt udførligt festskikkene i Europa omkring 
Mardi Gras);7 Bakhtin gør eksplicit opmærksom på middelalderens og renæssancens mangfoldige diableries og deres subversive sociale funktion: „Skuespillerne, der var forklædt som djævle, følte at de på en eller anden måde havde kastet de sædvanlige snærende bånd af sig, og de overførte denne følelse til dem der kom i kontakt med dem. De skabte en atmosfære af løssluppen karnevalistisk frihed ('an atmosphere of unbridled carnivalesque freedom')..."8 Protagonisten i Ishmael Reeds western-travesti Yellow Back Radio Broke-Down (1969) får på tilsvarende måde del i den ekstravagante frihed, som kendetegner karnevalskulturen: den sorte cowboy, the Loop Garoo Kid, begynder således i denne roman sin karriere i et rum og sprogligt register man kender fra markedspladsens og cirkusarenaens højøstede samkvems- og kommunikationsformer; men gradvis afsløres flere og flere "dæmoniske" træk hos hovedpersonen, indtil det bliver åbenbart at han hører til på et højere mytisk og kosmologisk plan og i virkeligheden er ingen ringere end hans sataniske majestæt himself $\mathrm{i}$ egen høje (eller lave) person! I denne roman karnevaliserer Ishmael Reed med andre ord hele det mytologiske apparat kristendommen benytter sig af, og i stedet relativeres begreberne om godt og ondt (den kristne metafysik) og spilles ud imod hinanden på helt nye måder (ifølge Mikhail Bakhtin er en sådan "munter relativisme" netop karakteristisk for karnevalskulturen og dens litterære frembringelser). 9

I det følgende vil jeg især koncentrere mig om Ishmael Reeds to tresserromaner, d.v.s. The Freelance Pallbearers (1967) og Yellow Back Radio Broke-Down (1969); men jeg vil også komme nærmere ind på en af de romaner som ofte fremhæves som et litterært højdepunkt inden for forfatterskabet, d.v.s. den burleske (og apokalyptiske) collageroman Mumbo Jumbo (1972). Derudover vil jeg mere summarisk henvise til The Last Days of Louisiana Red (1974) og andre af hans senere romaner (f.eks. campus-romanen Japanese by Spring, 1993, 1994). Men med det fokus som antydes ovenfor bliver vi (når vi tager hensyn til nødvendigheden af historiske perspektiveringer og præciseringer) i alt væsentligt i stand til at bevæge os inden for rammerne af tresserkulturen og dens forskellige (tematiske og narrative) registre - og det bliver i den sam- 
menhæng muligt at iagttage, hvordan Ishmael Reed både reflekterer samtidige strømninger og (sub)kulturelle tendenser og i sin prosa udvikler nye udtryksformer og retoriske greb. Under alle omstændigheder spiller han på nogle litterære koder, som især forbindes med den litterære avantgarde i tresserne og som man (i forskelligt omfang) kan genfinde hos samtidige forfattere som Thomas Pynchon eller William S. Burroughs; således iscenesættes i hans prosa hyppigt demonstrative brud på det lineære, (krono)logisk opbyggede fortælleforløb (jf. hans systematiske brug af anakronismen som fortælleteknisk greb), og derudover er Reeds sprog i denne periode ofte rablende, surrealistisk og/ eller vildt fabulerende, samtidig med at man hos ham kan iagttage en række konsekvente overtrædelser af enhver (regelret) mimetisk praksis. I et videre socio- og kulturpolitisk perspektiv kan man inden for samme tidsrum (fra ca. 1967 til midten af halvfjerdserne) ligeledes hæfte sig ved, hvordan ungdoms- og studenteroprørets ekstravagante livsstil (med fokus på psykedeliske "trips" eller "indre rejser") til at begynde med både trækkes tydeligt op og (så at sige) konstituerer selve det psykiske landskab i romanuniverserne, mens det på den -anden side fra og med Mumbo Jumbo (1972) i højere og højere grad bliver et mørkelagt og konspiratorisk univers der aftegner sig i Reeds nygotiske (og stadigvæk stærkt karnevalișerede) fantasirum. I den forbindelse kan man naturligvis ikke undgå at tænke på, at det i høj grad er et (politisk) angst- og mareredet Amerika vi har at gøre med i slutningen af tresserne og i halvfjerdserne, et Amerika hvor forfølgelsesforestillingernes fantasmatik så at sige er gået i opfyldelse - for efter mordene på de to Kennedy' er og på Malcolm X og Martin Luther King, efter Warren-kommisionen og under indtryk af Vietnam-krigens tiltagende barbari, făr vi tydeligere og tydeligere øje på det Amerika, som Watergate (og præsident Nixons afgang) ved halvfjerdsernes begyndelse på sæt og vis blot er den logiske konsekvens af. Fra flip- og trip-kulturens ekstravagante ekseesser (Timothy Leary, Carlos Castaneda, et al.) bevæger vi os i denne periode gradvis over i en kulturpolitisk situation, hvis altdominerende karakteristikum tilsyneladende er paranoiaen (inden for det litterære felt eksemplificeret af forfattere 
som Pynchon og Reed, og i filmen af en række film fra halvfjerdserne og de tidlige firsere, fra Alan Pakulas The Parallax View, 1974, og All the President's Men, 1976, til David Cronenbergs The Dead Zone, 1983, og Videodrome, 1983). Men herom senere.

\section{The Freelance Pallbearers}

Pratagonisten i Ishmael Reeds debutroman The Freelance Pallbearers (1967) hedder (som tidligere anført) Bukka Doopeyduk, og selve hovedpersonens navn spiller begribeligvis på - og siger noget om - både hans psykologiske habitus og hans placering $\mathrm{i}$ forhold til nogle eksisterende afto-amerikanske (politiske og kulturelle) traditionssammenhænge: på den ene side antyder hans efternavn, at han er let at tage ved noesen (jf. (to) , ,dupe" = (at) "snyde", ,løbe om hjørner med", etc.), men på den anden side rummer'hans fornavn (,Bukka") uden tvivl også en "skæv" reference til the grand old man inden for en veletableret integrationistisk (og i nogen grad konformistisk) afro-amerikansk tradition,. dvs. til Booker T. Washington (1856?-1915), forfatter til en berømt selvbiografi, Up from Slavery (1901), ogtalsmand for en udsoning mellem sorte og hvide i Sydstaterne, en udsoning som i nogen grad kom til at betyde et de facto afkald på politiske rettigheder for de sortes vedkommende. Booker T. Washington havde også i meget høj grad internaliseret den protestantiske arbejdsetik (og den puritanske -moralkodeks og forestillingsverden i det hele taget), hvad der korresponderer meget godt med, at Bukka Doopeyduk i The Freelance Pallbearers er blevet indoktrineret i den såkaldte "nazaræiske" troslære og ·dens doktriner (den nazaræiske trosretning er helt klart modelleret over WASP-ideologien og dens basale dogmer(!)). Men samtidig fokuserer Reeds roman med pedantisk (over)tydelighed på hvad Mikhail Bakhtin har kaldt the material bodily lower stratum, og den nazaræiske apokalypse (som der henvises til flere steder i plottet) spiller ud i det grotesk-korporlige på en måde, som erindrer os om den amerikanske, freudiansk inspirerede kulturkritiker Norman 0 . Browns refleksioner over den ekskrementale vision i den vestlige kultur. $1^{\circ}$ Alteret eller templet i denne kult er nemlig et lokum(!), 
sådan som det bliver fremstillet tongue-in-cheek i en beskrivelse af en "frise" med apokalypsens hovedfigurer:

Den [dvs. frisen] viste HARRY SAM, diktatoren og den tidligere polske brugtbilsforhandler, siddende på det store lokum. På hans skød sad en forretningsmand, en nazaræisk discipel og et sort barn fra slummen. Disse figurer repræsenterede de retfærdige. Stående på begge sider af diktatoren var der fire toilet-assistenter. I deres hænder havde de syv børster, syv kamme, syv håndklæder og syv stykker sæbe, en lok af Roy Rogers' hår og en Hershey-bar. Oven over figurerne flyder der Lawrence Welk champagne-bobler. Under denne scene er gravstenene blevet rullet tilside og de nazaræiske troende kan ses stige tilvejrs $i$ en tåge med deres hænder strakt ud mod $\mathrm{fi}_{\mathrm{g}}$ ren der sidder på lokummet.11

Johannes' Åbenbaring - med de syv kirker i Asien, de syv dommedagsbasuner, etc. - er blevet omskrevet til ukendelighed og meget demonstrativt (gen)læst i det moderne amerikanske forbrugersamfunds billede (!). Guddommen er blevet brugtbilsforhandler (og endda østeuropæisk immigrant(!)), de fire livsvæse.ner er blevet toilet-assistenter og syvtallet optræder her kun i forbindelse med de hverdagslige trivia, som opremses som en slags ikoner eller relikvier i det store ekskrementale tableau (, syv børster, syv kamme, syv håndklæder og syv stykker sæbe"); de troende bliver ikke (længere) vasket i Lammets blod, men det er (tilsyneladende) brugtbilsforhandleren selv, der får personlig forplejning på sit das. I optrinnet balanceres der således hårfint imellem på den ene side en form for verdslig askese a la Weber (et renselsesritual) og på den anden hvad Anker Gemzøe engang har kaldt for "kneppe-æde-drikke-skide-pisse-planet". 12 For vi har allerede fået at v:ide ved romanens begyndelse, at grunden til at HARRY SAM troner på sit das på bemeldte måde er at han for tredive år siden "forsvandt ind på lokummet med en besynderlig lidelse som hjemsøgte ham",13 dvs. han har (bogstavelig talt) været på skideren i en hel menneskealder.

Amerikansk efterkrigshistorie travesteres på burlesk vis en række steder i The Freelance Pallbearers. Richard Nixon og frue optræer eksempelvis sammen med deres hund Checkers, som bliver bortført under dramatiske omstændigheder i kapitlet "An 
Old Woman Kidnaps Checkers"; hele optrinnet orkestreres i bogstavelig forstand som et Marx Brothers slapstick-nummer, hvor the stateroom "tømmes efterhånden som de gamle mænd forfølger enke-bødlen der holder cockerspaniel'en der bliver forfulgt. af Nixon'erne som er i hælene på... eller er det krigsveteranerne der forfølger generalerne der forfølger Nixon'erne?"14 Med en åbenlyst parodisk hentydning til senator McCarthys berygtede høringer i halvtredserne refereres der til høringer om fugle i samme periode(!). O.s.v., o.s.v.

Bukka Doopeyduk er som sagt blevet hjernevasket af systemet, og på et tidspunkt får han som belønning for lang og tro tjeneste (som sygemedjælper på et hospital) „ET GYLDENT STIKBÆKKEN", 15 dvs. der bliver her igen på parodisk vis fokuseret på the material bodily lower stratum og den ekskrementale (tilværelses) vision a la Norman 0 . Brown. Men i den sammenhæng er det også nærliggende at henvise til nogle litterære og filosofiske forgængere, som på li $i_{\mathrm{g} n}$ ende måde kæder pengeøkonomi (kapitalisme) ogfoeces sammen. Ifølge Freud er pengepugeren (a la Joakim von And) som bekendt ekstremt analfikseret, og Freud iagttager overalt, i.myter, eventyr og overtroiske forestillinger, og mere generelt i ubevidst tænkning overhovedet, foruden i drømme og neuroser, hvordan "penge bliver bragt i tæt forbindelse med skidt", ligesom mammon "ifølge en gammel babylonisk doktrin" er lig med "Helvedes fæces"! 16I William Morris' utopiske romance News from Nowhere (1890) optræeder der karakteristisk nok en "Gylden Skraldemand", som holder meget af prangende klædedragter og har for vane at "iføre sig så meget guld som en baron i Middelalderen."17 I Morris' utopiske fremtidssamfund er guld afskaffet som byttemiddel og almindelig ækvivalent, og alle og enhver kan benytte sig af det efter forgodtbefindende (det har kun bibeholdt en rent oestetisk funktion) men på den anden side er det nok heller ikke noget tilfælde at det er en skraldemand, som lader sig forgylde på den måde (jf. Freud om sammenhængen mellem mammon og skidt/fæces). For Ishmael Reeds vedkommende indgår alle disse topoi begribeli $i_{\mathrm{g}}$ is $\mathrm{i}$ en narrativ strategi, hvor en række af senkapitalismens og forbrugersamfundets basale selvforståelsesformer og ideologiske 
idiosynkrasier udsættes for ironiens syrebad eller en omgang satirisk spanking.

Bukka Doopeyduks karriere tager et styrtdyk, da han ikke blot bliver skilt fra sin kone (Fanny), men også fyret fra sit job på hospitalet (som kræver det gyldne stikbækken tilbage!), og på dette tidspunkt bliver det - karakteristisk nok - teaterverdenen og showbusiness, der tiltrækker ham (og hvor han midlertidigt bliver i stand til at finde sit udkomme). I en af amerikansk litteraturs klassiske anti-dannelsesromaner - en roman som uden tvivl spøgte i baggrunden, da Reed skrev The Freelance Pallbearers - dvs. Nathanael Wests satiriske burleske A Cool Million (1934), tegner hovedpersonen Lemuel Pitkins sociale deroute en lignende permanent nedadgående kurve, og også her fører protagonistens (anti)karriere som social paria ham ind i tvivlsomme jobs inden for showbusiness (f.eks. i det omrejsende "Chamber of American Horrors" og i en teaterforestilling, hvor Pitkin i bogstavelig forstand bliver priigelknabe og med jævne mellemrum slået "på kroppen og i hovedet med [...] sammenrullede aviser" af to (med)komedianter.18 En lignende syndebuk-rolle får Bukka Doopeyduk tildelt i en happening arrangeret af det såkaldte "Entropy Productions"-kompagni (ledet af en mand med det megetsigende navn "Cipher X"(!)): „Jeg stak min hals og mine hænder ind i gabestokken og knælede på puden. Gabestokken smækkede i."19 Hvad der tematiseres i denne dubiøse teaterproduktion har imidlertid også helt klare apokalyptiske overtoner, og da bifaldet brager løs efter forestillingen, har Bukka Doopeyduk svært ved at tro på, ,,at publikum applauderede sin egen undergang." (20

Happening-formen er en dramatisk genre, som netop er intimt forbundet med tressernes alternative kulturelle praksisser og eksperimenterende livsstil (i The Freelance Pallbearers bruges betegnelsen "BECOMING" i stedet for happening (?).21 Men andre sider af tressernes modkultur(er) optræder også i Reeds roman, hvor der f.eks. henvises direkte til LSD-profeten Timothy Learys motto: „Drop out Turn on. Tune in"22 i en samtale mellem Bukka Doopeyduk og hans professor (U2 Polyglot): ${ }_{11} \mathrm{~N}$ uvel, på den anden side, når du dropper ud og tuner ind, kan det være du 
bliver tændt på det, Bukka. Hvem ved?" („Well, on the other hand, maybe dropping out and tuning in will turn you on, Bukka. Who knows?").23

At Bukka Doopeyduk kommer til at arbejde for et foretagende, som hedder "Entropy Produetions" er iøvrigt både interessant og i overensstemmelse med tidsånden i tresserne. Entropibegrebet spiller i denne periode en tiltagende rolle i de løbende kulturelle debatter både i U.S.A. og Europa (f.eks. i forbindelse med informationsteorien), og Thomas Pynchon er jo netop en af de tresserforfattere der har bidraget til at give dette begreb en karakteristisk litteroer prægning (cf. også tematikkens tilstedeværelse hos en science-fiction forfatter som Ballard). Et af Pynchons tidligste arbejder er novellen "Entropy" (1960), første gang trykt i The Kenyon Review, hvor hovedpersonerne tilsidst kun kan vente resigneret på det Øjeblik i den kosmiske historie, „,hvor 37 graders Fahrenheit ville råde både ude og inde, og hvor deres adskilte livs svævende, besynderlige dominant ville opløse sig i en toning af mørke og det endelige fravær af al bevægelse."24

En sådan bevægelse henimod en tilstand af forskelsløshed er på den anden side ligeledes hvad der karakteriserer grotesken som litterær form (eller i billedkunsten). Som det er blevet formuleret af Ronald R. Paulson: „Forskelsløshed ['Undifferentiation'] er et kendetegn som grotesken og det gotiske har tilfælles ... [og] både det gotiske og grotesken fokuserer på momentet af fremmedgørelse, overgangen mellem denne og hin. verden [dvs. normalverdenen og en dæmonisk anti-verden], hvor planten og mennesket er under forvandling og man næppe mere kan kende forskel på dem."25 Plante-, $d_{y r} \mathrm{e}$, og menneskeverden smelter sammen i grotesken, og noget tilsvarende kan man iagttage i The Freelance Pallbearers, hvor Bukka Doopeyduks halvfemsårige svigerfader karakteristisk nok bliver tildelt iøjnefaldende " $d y$ riske" attributter:

Som en halvfemsårig miserabelt udseende mølkugle havde han hang til at sutte på tommelfingeren og leve med en stemme som i [t.v.-serien] Tales of the Crypt samt dekorere sit hus med hæklede puder med Niagara Falls på. Han havde været præsident. for de farvede Elge i 1928 og engang kysset Calvin Coolidge i røven. $\mathrm{N}$ u sad han i sit hus hele dagen 
og drak Champale maltlikør og så på t.v.-melodramaer i dagtimerne. Et gevir med spindelvæv hvilede på hans hoved. ${ }^{26}$

Tegn og underlige gerninger varsler om de sidste tider i The Freelance Pallbearers, hvor protagonisten allerede i den føromtalte happening (BECOMING) bliver forvekslet med Jesus-på-korset af en forretningsmand blandt tilskuerne („Tror De det er Kristus, der hænger ud fra korset" [„Do you think it's Christ hanging off the cross?" (sic!)]_27 Men da Bukka Doopeyduk i romanens sidste kapitel bliver ophængt i kødkroge i Kejser Franz Josef-parken (se ovenfor), kan det (rette) apokalyptiske klimaks ikke effektueres, i og med at the material bodily lower stratum endnu engang kommer på tværs. Bukka Doopeyduks gamle universitetslærer dukker i løbet af plottet flere gange op med en gigantisk kugle af gødning, som han tålmodigt prøver at trille hele vejen rundt om jordkloden(!) - i et forsøg på at imitere (eller blive som) helten i Franz Kafkas "Die Verwandlung" (1912), dvs. Gregor Samsa, der som bekendt en morgen vågner op og opdager at han i nattens løb er blevet "forvandlet til et kæmpemæssigt kryb" (,zu einem ungeheueren Ungeziefer verwandelt").28 I The Freelance Pallbearers bliver de apokalyptiske sørgemarskaller ganske enkelt forhindret i at udføre deres job (dvs. at skære Bukka Boopeyduk ned): „Der var denne her kugle af gødning som hang over Klanga-Lang-a-Ding-Dong [det imaginære land hvor plottet udspiller sig]. Den blev holdt nede af spigrer og reb og stanken var så gennemtrængende, at den nåede helt op til himlen..." Selvom Bukka Doopeyduks gamle lærer (med det meget sigende navn U2 Polyglot) har højtravende planer, forbliver han (vi allesammen) hele tiden med næsen i møget! Og den store fortælling om frelse, fortabelse og/eller dommedag nu kan ikke føres ud i livet, sålænge vores groteske bånd til dyreriget og the material bodily lower stratum holder os fast i den materielle sfære.

Sproget selv er inficeret af den samme omvendingslogik som den der knytter sig til det tematiske plan i romanen: navnene i plottet er hele tiden "talende navne" (Tynjanov), ${ }^{29}$ og Reed spiller mange slags idiomer og diskurser ud mod hinanden, samtidig med at selve navngivningsfunktionen bliver kørt igennem det satiriske maskineri; for hvad ska:1 man stille op med navne 
som Bukka Doopeyduk, Eclair Porkchop, Dommer Eberett Whimplewopper (en dværg som må stå på tre telefonbøger for at se ud i retssalen (!)), Nosetrouble (revolutionær marxist), M/Neighbor, Cipher X, SAM (landets diktator), o.s.v., o.s.v. Og når landet hedder "Klang-a-Lang-a-Ding-Dong". er vi tæt på Lewis Carrolls og Edward Lears verbale lydmalerier og nonsens-

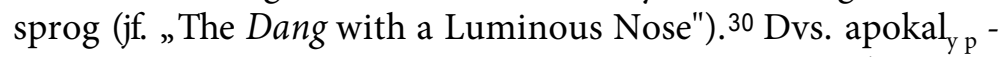
sen indoptager groteskens virkemidler og kropsnære ethos, samtidig med at verdens undergang tematiseres som et sprogligt sammenbrud af en vis størrelsesorden. Men det er en anden historie - og den kan ikke (længere) fortælles lige ud ad landevejen som en "stor fortælling".

Der er endnu et punkt, hvor Reed i The Freelance Pallbearers bryder med gængse narrative regler (eller selve diskursens lov). Han lader nemlig sin protagonist blive ved med at berette efter at han (formelt og reelt) er død, hvad der begribeligvis er ensbetydende med en umulig deixis. Efter en længere tale pr senteres vi for jeg-fortællerens alias protagonistens (Bukka Doopeyduks) berømte sidste ord: „'....Hvad nytter det?' sagde jeg og opgav ånden, mens den lille mand tog sin derby-hat af og bøjede hovedet... "31 Her er fortælleren imidlertid i stand til at fortsætte sin rablende (indre?) monolog efter døden (lige frem til den store apo$\mathrm{kal}_{\mathrm{y}}$ tiske finale), og man·mindes i den forbindelse uvilkårligt Roland Barthes' berømte analyse af en fortælling af Edgar Allan Poe (, The Facts in the Case of M. Valdemar", 1845), hvor Barthes påpeger, at det forhold at Poe lader en person, som er blevet mesmeriseret i dødsøjeblikket, fortsætte med at tale fra den anden side af døden, er intet mindre end en sproglig skandale: „Det er reelt beset banalt at ytre sætningen 'Jeg er død' - det er hvad den kvinde siger, der har tilbragt hele eftermiddagen med at handle i Printemps, været hos sin frisør etc. I forbindelse med denne metafor er det udelukket at vende det metaforiske om til det bogstavelige..." 32 Men det er præcist sådan et lov-brud fortælleren i The Freelance Pallbearers gør sig skyldig i, da han fortsætter med at plapre løs efter at han har "opgivet ånden". 


\section{Yellow Back Radio Broke-Down}

I The Freelance Pallbearers befinder vi os i et mytologisk Amerika (HARRY SAM), som fortælleren simpelthen har vanskeligt ved at sætte på sprog, i og med at det imaginære land (sted) er blevet udstyret med flere (altfor mange) navne for (så at sige) at fastholde eller artikulere det inden for rammerne af den symbolske orden (det hedder f.eks. allerede i første kapitel, at dette utrolige sted eller ikke-sted, altså HARRY SAM, som tilligemed er "udeaf-syne", til overflod også kaldes for "0-BOP-SHE-BANG eller KLANG-A-LANG-A-DING-DONG"). 33 Forsåvidt som den narrative diskurs $\mathrm{i}$ The Freelance Pallbearers i eminent forstand befinder sig inden for et fantastisk register, er det ligeledes klart, at Reeds første roman i høj grad repræsenterer et brud med mimetiske eller realistiske skriftkonventioner. Mens vi i The Freelance Pallbearers i det store og hele befinder os i nærheden af den amerikanske østkyst (i N ew York eller på Manhattan), bevæger Reed sig i sin næste roman, Yellow Back Radio Broke-Down (1969) længere vestpå, i og med at han her forsøger at skrive sig op imod eller parodiere western-genren med alle dens mangfoldige gimmicks og faste stiltræk. Pratagonisten, the Loop Garoo Kid, har således en hel del tilfælles med klassiske western-helte eller anti-helte a la Jesse James eller Billy the Kid, der som bekendt i tidens løb har spillet en væsentlig rolle $\mathrm{i}$ den amerikanske western-mytologi (helt bp til Young Guns-filmene). Ifølge Linda Hutcheon appellerer western-genren i særlig grad til en række repræsentanter for hvad der (meget generelt) kan betegnes som postmodernistisk fiktion, i og med at vi her i eminent grad har at gøre med en genre som ikke kan tænkes uden for en (nord)amerikansk historisk kontekst og uden rekurs til samme (nord)amerikanske kontinents grundlæggende myter; det står i den sammenhæng den postmodernistiske skribent frit for at revidere historien (mere eller mindre) efter forgodtbefindende ved at blande kortene på nye måder: „ "... den ironiske intertekstuelle brug af western-genren er ikke... en form for 'eskapistisk ophævelse af tiden' ['Temporal Escape'] ... , men snarere en måde at komme til rette med de eksisterende traditioner på, sådan som de foreligger i form af tidligere historiske og litterære udformninger af det særligt ameri- 
kanske ['earlier historical and literary articulations. of Americanness']. I den sammenhæng er det klart, at parodien kan bruges til satiriske formål."34 En forløber for denne ironiske intertekstuelle brug af western-genren finder man allerede i Nathanael Wests tidligere omtalte A Cool Million (1934), hvor anti-helten Lemuel Pitkin kommer gruelig galt afsted i det vilde Vesten. Men også senere forfattere som Richard Brautigan og William S. Burroughs dekonstrueret på lignende vis genren og dens store fortællinger i henholdsvis The Hawkline Monster. A Gothic Western (1974) og The Place afDead Roads (1983).35 I de to sidstnævnte tilfælde er der helt klart om en eksplicit postmodernistisk brug af (eller leg med) genreskabeloner og -virkemidler, hvor selve fortælleforløbet underminerer hævdvundne forestillinger om det vilde Vesten.

Den karnevalistiske larm og forvirring som rådede i The Freelance Pallbearers sætter også sit markante præg på den narrative strategi i Yellow Back Radio Broke-Down: I første kapitel (, The Loop Garoo Kid Goes Away Mad") præsenteres protagonisten som omrejsende cirkusartist, og til hans trup hører ligeledes en hurtigsnakker, en jonglør, en spåkvinde fra New Orleans (Zozo Labrique) og en dansende bjørn. Da de ankommer til byen Yellow Back Radio langt ude vestpå, er stedet imidlertid blevet overtaget af en gruppe børn, som har fordrevet alle voksne og praktiserer børnemagt på en helt bogstavelig måde:

Den Dansende Bjørn, Jongløren, Loop og Zozo underholdte børnene til langt ud på natten. Den Dansende Bjørn udførte akrobatiske numre på en meget behændig måde, Loop optrådte med sine lasso-tricks, og Zozo læste ibørnenes hænder og gav dem besked om deres fremtid.36

Amerikansk historie optræder igen i grotesk-fordrejet form i Yellow Back Radio Broke-Down, hvor børnenes oprør i Yellow Back Radio minder os om de sene tresseres ungdoms- og studenteroprør (maj 1968, o.s.v.); vi noterer os i den forbindelse, at romanen er blevet afsluttet i Oakland, Californien, i juni 1968 (dvs. en måned efter maj 68 i Frankrig); og at Oakland ligger meget tæt på Berkeley, Californien, hvor tilsvarende uroligheder og radikale studenterbevægelser satte deres præg på universitetslivet i de sene tressere. Tressergenerationens motto: „Stol aldrig på en 
mand over tredive!" bliver i Yellow Back Radio til: „... Vi besluttede, at vi ikke mere ville stole på nogen der havde grå tindinger!"37 I Yellow Back Radio Broke-Down samler den lokale kvægbaron, Drag Gibson, en bande forhærdede gunmen og udøver voldelig selv-justits i Yellow Back Radio, idet han foranstalter et veritabelt blodbad på de oprørske børn; kun to af børnene og the Loop Garoo Kid undslipper den kyniske likvidering (i nordamerikansk sammenhæng kommer. man uvilkårligt til at tænke på massakren på Kent State University og, i større målestok, nedkæmpelsen af studenteroprøret i Mexico City).

Ligesom i The Freelance Pallbearers spilles der i Yellow Back Radio Broke-Down ud i et overnaturligt register; i The Freelance Pallbearers bliver hovedpersonen offer for sort magi (voodoo eller hoodoo) og kureres kun ved resolut indgriben fra sin professors side, idet han køber en anti-hoodo lotion af denne: „Hugtænderne faldt ud af munden på mig, og da de ramte gaden, splintredes de i fine krystaller... "38 (!). I Yellow Back Radio BrokeDown spiller den sorte magi en endnu mere fremtrædende rolle, idet både Zozo Labrique og the Loop Garoo Kid behersker de sorte kunster; da Zozo Labrique er blevet dødeligt såret under angrebet på Yellow Back Radio (ved nedslagtningen af børnene og cirkustruppen), presser hun en tand fra en gal hund ned i hånden på the Loop Garoo Kid og opfordrer ham til at bruge alle de magiske tricks han nogensinde har lært. Det gør han i deri kommende tid, og han anvender al sin magiske viden til at forhekse Drag Gibson, den føromtalte kvægbaron som foranstaltede massakren; Drag Gibson portrætteres i romanen som "den rigeste mand i dalen, med kvægflokke som trives glimrende, formidable ressourcer og et ego så stort som Grand Canyon" (!). 39

I Yellow Back Radio Broke-Down fokuserer Reed på modsætningsforholdet mellem på den ene side den lov- og fredløse sorte cowboy og lasso-kunstner the Loop Garoo Kid og på den anden systemets mand, magnaten og kvægbaronen Drag Gibson (hans navn antyder en vis mangel på stabil seksuel identitet!). Hos Reed har disse repræsentanter for en gennemkorrupt magtelite en iøjnefaldende tematisk gennemslagskraft i hans romanuniverser (især i de tidlige bøger): SAM i The Freelance Pallbearers, som oeder 
sine undersåtters børn (dvs. praktiserer kannibalisme), børnemorderen Drag Gibson i Yellow Back Radio Broke-Down og slaveejeren Arthur Swille i den historiske pastiche Flight to Canada (1975). Disse figurer repræsenterer, kunne man sige, faderlovens sammenbrud, og i Julia Kristevas karakteristik af de centrale tematiske elementer i Dostojevskis romanunivers formuleres meget præcist, hvad det drejer sig om; hun taler direkte om "de fædrene loves sammenbrud", og derudover fremlæser hun i en roman som De besatte "en verden af fædre som enten bliver forkastet, er svindlere eller døde, hvor magtsyge matriarker råder - rasende feticher, men ikke desto mindre fantom-agtige?"40

Opgøret med Drag Gibson antager i the Loop Garoo Kids tilfælde ødipale overtoner, og det er interessant at da the Loop Garoo Kid tilsidst står på skafottet, bliver han snydt for sit martyrium, og i stedet er det kvægbaronens hoved der ruller og ender i den uhumske svinesti bag skafottet; dvs. hvad der her føres ud i livet er det obligate (rituelle) fadermord, men patriarkens detronisering bliver samtidig gennemført så radikalt, at han i bogstavelig forstand trækkes gennem sølet og ender som svineæde eller "Cattleman a la carte" (!).41 dvs. den degradationsproces, som tematiseres i Yellow Back Radio Broke-bown, forbindes i bogstavelig forstand med hvad Julia Kristeva har kaldt det abjektale. Karakteristisk nok opløser alle faste former sig i det afsluttende shoot out på henrettelsespladsen, hvor Drag Gibsons cowboys må lade livet under et angreb med strålepistoler (!): „Kegle efter kegle af sære lys blev kastet på deres kroppe, og de smeltede langsomt sammen til en klistret masse. "42

Fra at være en mytisk cowboy, i besiddelse af en uovervindelig pistol og hele tiden i stand til at undslippe sine forfølgere, viser the Loop Garoo Kid sig (som tidligere anført) i sidste instans at være ingen ringere end Satan selv; hans uovervindelighed - og udødelighed - viser sig med andre ord at være metafysisk begrundet. Hans navn peger både i retning af europæisk folklore og overtro (jf. det franske ord for "varulv", dvs. loup garou) og i retning af western-mytologiens hævdvundne forestillingsverden (den uovervindelige gunman eller bandit a la Billy the Kid og Jesse James). I sidste instans bliver the Loop Garoos 
ærkemodstander ikke så meget den korrupte kvægbaron (Drag Gibson), men snarere paven selv som aflægger et overraskende besøg i det vilde Vesten. Religionshistorikeren Mircea Eliade taler i The Two and the One (udgivet i Frankrig i 1962 og på engelsk i 1965) om "blod-fællesskabet mellem Kristus og Satan og venskabet mellem Gud og Djævelen",43 og Yellow Back Radio Broke-Down munder netop ud i sådan en metafysisk forsoning mellem modsatrettede kosmiske kræfter, i dette tilfælde repræsenteret af henholdvis paven (det "gode") og the Loop Garoo Kid (det "onde"). Da pavens skib styrer hjemad mod Europa, bliver han på underfundig vis indhentet af den løsslupne djævel (the Loop Garoo Kid), som svømmer ud imod skibet sammen med sin grønne hest $\theta$

Paven styrtede til skibets ræling, mens han tyggede på en havana. Nej, Fanden stå i det, og halleluja, her kommer the Loop, smilede klrkefyrsten. Thomas Jefferson var blevet arbejdsløs, men det var også o.k $4^{4}$

I den foreliggende sammenhæng repræsenterer Thomas Jefferson både en idealisering af agrarkulturen og en demokratisk tradition, som kan forbindes direkte med den amerikanske ideologi (den amerikanske agrarmytologi har fundet mange politiske og kulturelle udtryk helt op til John Steinbecks The Grapes af Wrath, 1939, og efterkrigstidens cowboy-film). The Loop Garoo Kid begynder i første kapitel som omvandrende politisk agitator, samtidig med at han antager en række af det guddommelige barns karaktertræk (jf. Jung og Kerenyi): ${ }^{45}$

Han var født med en sejrsskjorte over ansigtet og fantom-agtige øreflipper, og han var en gemen nattetripper, som drog fra by til by og citerede Thomas Jefferson og lod banditter bygge et herberg rundt om sit geni.46

Da the Loop Garoo Kid i sidste kapitel er blevet forsonet med sin ærkerival inden for den metafysiske orden, dvs. med paven selv, er tingene ( hvert fald for en tid) blevet bragt på plads inden for den kosmiske økonomi - nyt og gammelt, Amerika og Europa, Djævel og Gud, sort og hvid magi, etc., etc., går lige op. En ensidig amerikanisme (a la Thomas Jefferson) er ikke længere aktuel. Det betyder samtidig, at kristendommen (og den amerikanske puri- 
tanisme) ikke længere blokerer for de åndelige og religøse kilder, som de sorte amerikaneres kulturarv repræsenterer. Hertil hører også voodoo- eller hoodookulten med alle de heksekunster der hører derindunder. En mod- eller subkultur, som spiller en væsentlig rolle i Ishmael Reeds tidlige romaner - også i mesterværket Mumbo Jumbo fra 1972, hvor de kulturelle modsætninger mellem WASP-kulturen og dens repræsentanter på 'den ene side og en anderledes sort livsstil på den anden fremstilles i dramatisk tilspidset form i en surrealistisk beretning fra de brølende tyvere, dvs. fra en periode som både er den amerikanske jazz' guldalder og de professionelle Spielverderberes forbudstid. I denne collageroman tager Reed et mere kompliceret litterært apparat i brug end i de to foregående romaner - og disse formelle eksperimenter gør (i en vis forstand) denne enestående roman til et værk sui generis.

\section{Mumbo Jumbo}

I Robert Elliot Fox' studie Conscientious Sorcerers. The Black Postmodernist Fiction of LeRoi Jones / Amiri Baraka, Ishmael Reed, and Samuel R Delany (1987) understreger denne kritiker på den ene side Reeds tidlige interesse for de sorte amerikaneres kulturelle rødder (for hvad der er det saregne ved den afro-amerikanske kultur) og på den anden side den tiltagende bevidstgørelse (markeret i hans fiktion) omkring et multikulturelt perspektiv, hvor han efterhånden bevæger sig"ud over den afrocentriske vision", og i og med at han når frem til en vision som er "amerikansk i pluralistisk forstand, hjalp Reed til med at åbne et rum for den sorte kultur ['blackness'], hvor den var var i stand til at fortolke sig selv påny, til endelig at se sig selv som et stort heterogent substrat ['one great heterogene'] inden for rammerne af en endnu videre heterogen kontekst."47 Denne betoning af det pluralistiske perspektiv hos Reed er vigtigt, når man skal forsøge at indkredse hans narrative strategi, den måde han spiller forskellige kulturer og traditioner ud imod hinanden , og især når man vil prøve at bestemme den måde hvorpå han f.eks. bruger voodoo- eller hoodoo-kulten både metaforisk og bogstaveligt i sin særlige (afroamerikanske) afart af den magiske realisme. Mens hoodoo (den 
amerikanske version af voodoo) spiller en forholdsvis begrænset rolle i The Freelance Pallbearers og Yellow Back Radio Broke-Down, får den imidlertid en langt mere afgørende og central placering $\mathrm{i}$ de efterfølgende romaner, Mumbo Jumbo (1972) og The Last Days af Louisiana Red (1974). Her bliver hoodoo-kulten i anderledes emfatisk forstand genbrugt - eller genfortolket - som en integrerende del af den afro-amerikanske kulturarv, og hermed bliver det multikulturelle perspektiv Fox henviser til (se ovenfor) samtidig trukket tydeligere op. I den sammenhæng er det ikke noget tilfælde at plottet i Mumbo Jumbo tager sin begyndelse i New Orleans, „den[ne] charmerende $b_{y}$, med dens blanding af spansk, fransk og afrikansk kultur", som Reed formulerer det i kapitel 148

I The Geopolitical Aesthetic. Cinema and Space in the World System (1992) taler Fredric Jameson om hvad han kalder for den "konspiratoriske tekst"; i hans øjne kan sidstnævnte teksttype, (ikke mindst) „opfattes [...] som en ubevidst, kollektiv indsats for at forsøge at finde ud af hvor vi er og hvilke landskaber og kræfter vi er stillet overfor i det sene tyvende århundrede, hvor rædslerne bliver forstærketi kraft af at de er skjult og i kraft af deres upersonligt-bureaukratiske karakter. Sammensværgelsesfilmen ('Conspiracy film') sætter et vildt kårdestød. ind lige i hjertet af alt dette, i en situation hvor det er hensigt og gestus ger tæller. Intet er vundet ved at blive overbevist om den definitive sandsynlighed i forbindelse med denne eller hin konspiratoriske hypotese: men i selve den hensigt at opstille hypoteser, i det begær som hedder kognitiv kortlægning- der tager visdommen sin begyndelse."49 Dvs. selve de(t) moderne samfunds bureaukratiske uoverskuelighed gør det nærliggende at hypostasere sådanne konspirations-teorier - og også her finder man en del af forklaringsgrundlaget, forsåvidt angår den konspiratoriske struktur i romaner som Ishmael Reeds Mumbo Jumbo og The Last Days af Louisiana Red (hvor amerikansk samtidshistorie, fra Kennedyaffæren til Watergate-skandalen, begribeligvis også spiller en væsentlig rolle).

Sammensværgelser og modsammensværgelser spiller en vigtig tematisk rolle i Mumbo Jumbo. Hemmelige organisationer læg- 
ger konspiratoriske planer og er (på den ene eller anden måde) involveret i indviklede magtspil og -kampe. Ifølge Robert Elliot Fox forudsætter Reeds konspirations-teori i Mumbo Jumbo eksistensen af

et hemmeligt selskab kendt under navnet den Atonistiske Vej, beskyttet af en militant organisation kaldet Gyldenlak-Ordenen ['the Wallflower Order']. En Aton-tilhænger er en som tilbeder Aton, den Ene Gud som Akhenaton (Amenhotep IV, 1379-1372 f.Kr.) påtvang sine panteistiske undersåtter, selvom disse efter hans død omgående vendte tilbage til deres traditionelle troslære og endda opgav den nye by som var blevet bygget af Farao som et centrum for den atonistiske gudsdyrkelse.SO

Denne nye ægyptiske guddom (Aton eller Aten) blev fremstillet som en solskive omgivet af en aura af stråler (forsynet med menneskelige hœender). Dvs. man kan i Aton- $\mathrm{d}_{\mathrm{y} r}$ kelsen både finde elementer af den klassiske (metafysiske) sol- og lysd $\mathrm{y}_{\mathrm{r}}$ kelse, som har domineret i den vestlige kultur igennem årtusinder, og samtidig spor af samme kulturs gennemgribende antropomorfisme.

Den atonistiske trosretning kan i Mumbo Jumbo i store træk oversættes til den jødisk-kristne monoteisme, som har været mere eller mindre enerådende $i$ den vestlige verden siden antikken (Akhenatons sold ${ }_{\mathrm{y} r}$ kelse er et af det første eksempler på en ren$\mathrm{d}_{\mathrm{y}}$ ket monoteistisk religion i vores kulturkreds, selvom denne kults levetid begribeli $i_{\mathrm{g}}$ is var meget kort). Amenhotep den Fjerdes styre var iøvrigt kendetegnet ved sine klart totalitore træk, idet denne Farao forsøgte at udslette sporene af alle andre guddomme på de officielle monumenter, m.v.

Gyldenlak-ordenen er imidlertid ikke den eneste organisation, som konspirerer i Reeds roman: i Mumbo Jumbo støder vi også på en række referencer til de middelalderlige tempelherrer, som ifølge senere, vidt udbredte myte- og rygtedannelser overlevede den brutale undertrykkelse i begyndelsen af det 14. århundrede og fortsatte deres aktiviteter under andre former i forskellige historiske sammenhænge og i andre hemmelige selskaber (eksempelvis hos frimureme).51 I Mumbo Jumbo dukker på et tidligt tidspunkt i beretningen selve tempelherreordenens stormester op. Han hedder Hinckle von Vampton (!), og han er tilsynela- 
dende i besiddelse af en helt uovervindelig livskraft, for han har holdt sig i live igennem århundreder (siden middelalderen). Under forfølgelserne i begyndelsen af det 14. århundrede var selvsamme Hinckle allerede på banen: „Hinckle slap væk. Tempelherrerne gik under jorden. En korrupt version af deres riter. eksisterer fortsat som frimureri, som De vil have bemærket også tidsfæster sin begyndelse til Salomons Tempel. Hvor Hinckle end rejste i Europa blev han holdt skjult af sympatisører fra generation til generation..." 52

Hinckle von Vamptons navn minder os både om den megalomane diktator i Chaplins The Great Dictator (1940) - han bliver som bekendt hele tiden hyldet med ordene: „Heil Bynkel!" - og om bærerens vampyragtige kvaliteter; dertil kommer der også via det pseudo-aristokratiske "von" nogle lettere germanske konnotationer (i bakspejlet peger intrigerne og magtkampene i Mumbo Jumbo uomtvisteligt også i retning af den europæiske fascisme, selvom Hitlers magtovertagelse endnu ligger nogle år fremme i tiden, i og med at handlingen i romanen udspiller sig i jazz- og forbudstiden i tyverne).

Tempelherrerne figurerer besynderligt nok flere andre steder i den historiografiske metafiktion, som så dagens lys i 1970erne og '80erne. I den sammenhæng kan jeg blot nævne den engelskmexikanske forfatter og maler Leonora Carringtons surrealistiske undergrundsklassiker The Hearing Trumpet (1974 på fransk, 1977 på engelsk), hvor tempelherreordenen - som i Reeds Mumbo Jumbo - spiller en lidet flatterende rolle (i dette tilfælde som den orden der bevogter den hellige gral eller, som den bliver betegnet i The Hearing Trumpet, gudinden Venus' „,hellige kop").53 Også i Umberto Ecos Foucaults pendul $(1988,1989)$ bliver hovedpersonen (studenten Casaubon) indspundet i et net af sammensværgelser og modsammensværgelser, ligeledes med komplicerede forbindelser til den middelalderlige tempelherreorden; i det næstsidste kapitel citerer Eco iøvrigt meget apropos Karl Poppers kommentar til den udbredte forekomst af sammensværgelsesteorier i den moderne verden: „Sammensværgelsen som samfundsteori [...] er en følge af, at Gud er bortfaldet som holdepunkt, og af det deraffølgende spørgsmål: 'Hvem har taget 
hans plads?'"54 Sammensværgelsen - menneskelige agenters ondsindede master plan - træder i stedet for det guddommelige forsyn og Herrens uransagelige veje!

I Leonora Carringtons The Hearing Trumpet er både den officielle kirke og den forkætrede tempelherreorden fortolket negativt, og i stedet fremhæves en ældgammel heksekult og en matriarkalsk frugtbarhedsreligion som positive modstykker til den herskende patriarkalske kultur og dens mange repressive manifestationsformer; i Mumbo Jumbo er på lignende vis både den gængse kristne monoteisme (her repræsenteret af Gyldenlak-ordenen) og tempelherrernes lyssky aktiviteter fremstillet $i$ et negativt perspektiv. I stedet er det den sorte kulturarv - med dens polyteistiske mangfoldighed(er) - der trækkes frem; her er det især Papa LaBas og hans hemmelige virke - som et menneske med en indgående viden om magi, voodoo eller hoodoo - der fremhæves i plottet. Papa LaBas betegnes i romanen som "middags-hoodoo, eneboer-flygtning, obeah-mand, botaniker, $\mathrm{d}_{\mathrm{y}} \mathrm{eimitator}$, mand med to hoveder, kald-det-hvad-du-vil...",55 dvs. han befinder sig helt klart også i nærheden af det groteske (mellem)område, hvor menneske-, $\mathrm{d}_{\mathrm{yr}} \mathrm{e}-\mathrm{og}$ planteformer er viklet ind $\mathrm{i}$ hinanden.56 I romanens epilog som udspiller sig i nutiden (dvs. 1960erne) har Papa LaBas fået en betydningsfuld rolle som formidler mellem fortid og nutid, de sorte amerikaneres åndelige arv og en radikal, politiseret samtid:

Hvert år plejede de studerende at invitere Papa LaBas til universitetet for at diskutere Harlem-renæssancen. Trods alt havde han været tilstede under denne "neger-vækkelse". Han havde besøgt kabaret'erne, smugkroerne, og han kendte de mange malere, folk i showbusiness, filminstruktørerne [...] Men de unge mennesker så ud til at være mere interesseret $\mathrm{i}$ den kendsgerning at han var hundrede år gammel end $\mathrm{i}$ nogetsomhelst andet.57

Formelt anvender Ishmael Reed i Mumbo Jumbo en særlig collage-teknik, hvor mange forskellige genrer blandes med hinanden og (tilsammen) kommer til at udgøre et broget, kalejdoskopisk hele: i romanen er der både fortløbende beretning, indsatte annoncer og breve, avisnotitser, citater fra videnskabelig littera- 
tur (med præcise kildeangivelser i fodnoterne), en bibliografi, etc., etc. Rammeberetningen om Papa LaBas og hans forbundsfæller og deres kamp mod Gyldenlak-ordenen og. dens håndlangere (i dette tilfælde: tempelherrerne) suppleres på et andet (mytisk) fortælleplan af en stærkt revideret version af en række fortællinger fra den oegyptiske mytologi, først og fremmest beretningen om Osiris og hans voldsomme offerdød („De lemlæstede ham og fik folk til at tro, at han varplevet flået i 14 stykker af fisk, og fra den dag er fisk blevet opfattet som onde i Ægypten"). 58 Men en svindler ved navn Moses - som ellers har en mere flatterende rolle i den jødisk-kristne tradition - benytter sig til egne selviske formål af den viden hans indsigt i Osiris-kultens hemmeligheder har givet ham - og grundlægger endnu en monoteistisk religion (Reeds polemiske sigte med denne revisionistiske læsestrategi er åbenlys)!

På dette sted nærmer beretningen sig (endnu engang) et apokalyptisk fortælleplan - men iøvrigt er der talrige andre apokalyptiske elementer i romanen. Mumbo Jumbo er således tematisk koncentreret om en mærkelig "epidemi" $i$ tyvernes U.S.A., der $i$ romanen har fået navnet ${ }_{11}$ Jes Grew" (og som dukker op allerede i det indledende New Orleans-kapitel). Det hvide Amerika bekæmper denne "Jes Grew"-epidemi med alle midler, for det viser sig at den er nært forbundet med selve den afro-amerikanske livsstil, med det dionysiske i de sorte amerikaneres kultur; eller som det bliver formuleret allerede i det første kapitel:

Ivirkeligheden var Jes Grew en anti-pest. Nogle former for pest fik kroppen til at visne bort. Jes Grew fik sin værtsorganisme til at live op... Nogle former for pest opstår i dyr der ligger og rådner, men Jes Grew er ligeså elektrisk som livet selv og dens kendetegn er overflod og ekstase. Frygtelige pestsygdomme skyldes Guds vrede; men Jes Grew er Gudernes glæde. 59

"Jes Grew" er det der bare spontant opstår af sig selv (,,it just grew... 11, men alligevel søges denne anti-pest hele tiden inddæmmet og elimineret af myndighederne, som opfatter den som en 
alvorlig trusel mod systemet i sig selv, proecis fordi den ikke kan kontrolleres.

Med i sammensværgelsesplottet hører også jagten på en ganske bestemt bog, som angiveligt afslører de første og sidste ting (og som "Jes Grew" har brugfor, hvis den skal realisere sin "mission"). Henimod slutningen af romanen bliver det klart, at Bogen er blevet brændt (den æske der indeholdt den viser sig simpelthen at være tom). Dvs. hvad Reed her demonstrativt påpeger er (kunne man sige), at transcendensen er tom (cf. Hugo Friedrich om den"tomme transcendens" eller den"tomme idealitet" som konstitutive, idealtypiske træk ved det modernistiske projekt).60 Denne intethedsoplevelse figurerer iøvrigt mangfoldige steder i modernistisk poesi og prosa, som vi kender den fra mellemkrigstiden og mere specielt fra tyverne, dvs. det årti handlingen i Mumbo Jumbo for størstedelens vedkommende udspiller sig i (cf. T.S. Eliots "The Hollow Men", 1925, og Hemingways berømte nada-y,-pues-nada-y-nada-y-pues-nada-formel fra "A Clean, WellLighted Place", 1933).61 Et af de mest iøjnefaldende eksempler fra perioden finder vi i Dashiell Hammetts The Maltese Falcon (1930), hvor den (af alle) efterstræbte guldfetich (malteserfalken) tilsidst viser sig at være en værdiløs kopi (af $b l y) .62$

Det ægyptiske plot viser sig også at være apokalyptisk, idet Reed (meget anakronistisk) lader en veritabel atombombeeksplosion finde sted længe før vor tidsregning i det gamle Ægypten (den er folkeforføreren Moses' værk og illustrerer med forbilledlig klarhed den monoteistiske kodeks' destruktive potentialer!): "Så vendte folket sig mod Nilen og så en uhyre paddehattesky stige op mod himlen. "63 I sin artikel "The Whiteness of the Bomb" gør Ken Cooper i den forbindelse opmærksom på, at Moses' magiske formåen ifølge Reed er højst problematisk (en perverteret form for voodoo eller hoodoo): „Ligesom det gælder for Set [Osiris' rival] og Faust, repræsenterer de paddehatteskyer Moses fremmaner kun en overfladisk teknologisk "beherskelse" som bunder i et dybere selvbedrag og en mere grundlæggende parahoia."64 Paddehatteskyen - Manhattanprojektet og alt hvad der senere fulgte - er Aton-lærens eller den monoteistiske lovreligions yderste konsekvens! I The Freelance Pallbearers standser 
hovedpersonens (Bukka Doopeyduks) lommeur karakteristisk nok "kl. 3 om morgenen den 6. august, 1945",65 dvs. i det øjeblik den første atombombe eksploderer over Japan (Hiroshima). Ishmael Reed kredser med andre ord gang på gang om dette sandhedens øjebliki Vestens (og hele verdens) historie!

\section{Fra The Last Days of Louisiana Red til Japanese by Spring} I sine efterfølgende romaner fokuserer Ishmael Reed stadigvæk på totaliteten som sammensvorgelse (Jameson), hvadenten det som i The Last Days of Louisiana Red (1974) drejer sig om fejder og stridigheder fra kyst til kyst mellem forretningsforetagender og/ eller hemmelige organisationer som Louisiana Red Corporation og Solid Gumbo Works (big business versus en traditionel afroamerikansk, „magisk" baseret kultur) eller det handler om skumle politiske intriger i Washington og omegn som i The Terrible Twos (1982) og The Terrible Threes (1989). I alle disse senere romåner spiller Reed under alle omstændigheder over i et overnaturligt register, hvor der tydeligvis er tale om forbindelser til den magiske realisme, sådan som vi f.eks. kender den fra en latinamerikansk sammenhæng.

I The Last Days of Louisiana Red er hovedpersonen endnu en. gang Papa LaBas (som vi kender fra Mumbo Jumbo), og denne gang bliver han sendt på en mission til Californien (Berkeley), hvor han skal forsøge at udrede trådene eller løse mysteriet, efter at et mystisk mord har fundet sted derovre. Som vi allerede har gjort opmærksom på er Papa La.Bas indviet i voodoo- eller hoodoo-kultens ritualer, og både hans og hans forbundsfællers arbejde er koncentreret om "gumbo", som ifølge The Picayune Creole Cook Book er "en sær lig fremragende type kogekunst, $\mathrm{d}_{\mathrm{y}}$ ket og udviklet af de berømte kogekoner med kreolerblod i årerne i det gamle New Orleans."66 Gumbo har dog ikke blot noget at gøre med kogekunst, men i videre forstand med okkulte planer og strategier $\mathbf{i}$ et landsomfattende hemmeligt netværk - og med de sorte amerikaneres kulturelle arv og undertrykte traditioner i det hele taget Gumbo står i et modsætningsforhold til Louisiana Red, som karakteriseres på følgende måde i romanen: „Louisiana Red: tudseøjne, at putte slanger i folk, ekskrementer; fjendtlig- 
hed, ondskab, gøren-sig-til, negre der stikker negre ned-krabber i en tønde."67 Plottets fjendtlige kræfter repræsenteres først og fremmest af en fermme fatale ved navn Minnie the Moocher (hun kommer fra en berømt sang af Cab Calloway (!)), 68 men hendes rænker bliver efter mange genvordigheder forpurret - selvom Papa LaBas tilsidst i bogstavelig forstand må stige ned i underverdenen for at redde hende (Minnie the Moocher) fra evig (?) fortabelse!

I de første romaner - og her følges tematikken op i den parodiske slaveberetning Flight to Canada (1975) - fokuserer Ishmael Reed på mange måder på hvad man med Julia Kristeva kunne kalde for " de fædrene loves sammenbrud", dvs. faderfi ${ }_{\text {g u }}$ erne er i disse romaner i altovervejende grad fremstillet i et negativt lys: de er fjendtlige, destruktive repræsentanter for en patriarkalsk orden og legemliggør i forhold til de oprørske sønnefi ${ }_{\text {g u r }}$ er i mere eller mindre bogstavelig forstand en kastrationstrussel (jf. diktatoren SAM i The FreelancePallbearers, ranchejeren Drag Gibson i Yellow Back Radio Broke-Down og slaveeejeren Arthur Swille i Flight to Canada). I romaner som Mumbo Jumbo og The Last Days of Louisiana Red er det derimod de mere positive aspekter af fader-imago' et der understreges (jf. Papa LaBas' rolle som en gammel, quasi-jungiansk vismand og sjælefører i de to romaner). I The Terrible Twos (1982) og The Terrible Threes (1989) er det endnu engang en positivt investeret fader-fi $\mathrm{g}_{\mathrm{g} \text { r }}$ der har fået en betydningsfuld funktion i plottet, dvs. Julemanden (Father Christmas eller Santa Claus). Også i The Terrible Twos og The Terrible Threes er der tale om et konspiratorisk plot, hvor den politiske elite i USA har skumle planer om en radikal løsning på fattigdomsproblemet i form af den såkaldte operation ${ }_{1}$ Two Birds", i og med at man slår to fluer med et smæk, dvs. kaster atombomber over de største amerikanske bycentre og bagefter giver en afrikansk atommagt (sid) skylden og benytter lejligheden til at slette den pågældende nation fra landkortet!69Den amerikanske monopolkapitalisme triumferer $\mathrm{i}$ både The Terrible Twos og The Terrible Threes, og man må i den forbindelse have in mente, at begge romaner (som hænger sammen tematisk) er forfattet i yuppie-årtiet (firserne) eller Reagan-Bush-æraen, hvor USA som bekendt 
vandt den kolde krig og kapitalismen (i hvert fald for en tid) fik sat alle andre politiske alternativer ud af spillet (,Ebenezer Scrooge knejser over Washingtons skyline, mens han gnider sig i hænderne og stirrer grådigt ud over sine briller"), ${ }^{70}$

I Ishmael Reeds hidtil seneste opus, den parodiske collegeroman Japanese by Spring (1993, 1994), spiller det konspiratoriske plot en meget mindre iøjnefaldende rolle (selvom romanens protagonist helt utilsigtet bliver indblandet i en politisk sammensværgelse, som går ud på at myrde den japanske kejser!). På det tematiske plan er det snarere den multikulturelle dagsorden, som tiltrækker sig læserens opmærksomhed, og her er det interessant at Ishmael Reed tildeler sig selv (med navns nævnelse) en mindre rolle i plottet i Japanese by Spring og i den forbindelse understreger sin egert multietniske herkomst (denne cameo-optræden kan minde om Paul Austers tilsvarende funktion som romanfigur i hans egen City of Glass, 1985); i romanens epilog beskriver Reed således, hvordan han selv og datteren bliver nidstirret af en amerikansk fascist (en blond politimand), da de er på vej hjem fra Europa til Los Angeles i et Swissair fly: ,'Sølvræven' [dvs. politimanden] blev ved med at stirre på den raceblandede Ishmael Reed (afrikansk-fransk-irsk-cherokee) og hans raceblandede datter Tennessee (afrikansk-fransk-irsk-cherokee-russisk-tartarisk), begge to medlemmer af den raceblandede vestlige hemisfæres befolkningsflertal..."71 - dvs. frygten for raceblanding (som spiller så væsentlig en rolle i hele den vestlige ideologi) bliver her $\mathrm{i}$ Reeds roman undermineret på en subtil måde, og det viser sig at vi alle (i større eller mindre grad) er "medlemmer af den raceblandede vestlige hemisfæres befolkningsflertal" - racerene repræsentanter for de forskellige etniske grupper er det meget svært at finde.

\section{Epilog}

Ishmael Reeds forfatterkollega Joy Harjo slog engang fast over for denne (da han mødte hende i Tucson, Arizona): „Ishmael, Gud er en skalk ['trickster']."72 Ishmael Reed giver hende ret i

- denne opfattelse - dvs. i modsætning til den jødisk-kristne guddoms monolitisl<e træk (hvor Gud altid og til enhver tid er sig selv 
lig), er der her tale om en gud som ikke stemmer overens med sig selv, som hele tiden forvandler sig og antager nye skikkelser, osv., osv. Og Reed selv er også en litterær skalk (trickster), som det er meget svært at få hold på - som snart er et sted, snart et andet, og som i tilgift blander alle genrer og stilarter lystigt sammen i sine romaner (jf. f.eks. collage-teknikken iMumbo Jumbo). Øst og vest, Afrika og Amerika, støder ustandselig sammen og danner nye, overraskende kombinationer i hans fortællende prosa - han er brikolør snarere end ingeniør, og han er tilhænger af religiøs mangfoldighed snarere end af una sancta ecclesia, en sand Gud og en sand verdensorden. I mange af hans tekster står det gamle Ægypten for det Andet $i$ vores kultur, det som ikke lader sig reducere til den monoteistiske lovreligions snævre regelsystem og tyranniske sandhedsregimente. I digtet "The Jackal-Headed Cowboy" lader Reed således den klassiske cowboy-fi $\mathrm{gur}_{\mathrm{r}}$ smelte sammen med den ægyptiske mytologis $\mathrm{d}_{\mathrm{y}}$ eguddomme (jf. også de ægyptiske fortællespor i Yellow Back Radio Broke-Down og Mumbo Jumbo): den "sjakal-hovedede cowboy" rider vestpå, og "Anubis som er hurtig på aftrækkeren" (!) galopperer med på prærien med sine "skøre breve fra Ra" (sic!): ${ }^{73}$

and the Jackal-headed cowboy will ride reins whiplashing his brass legs and knobby hips. And fast draw Anubis with his crank letters from Ra will Gallop Gallop Gallop..74

The Loop Garoo Kid er tilbage i arenaen som en virtuos jonglør, der spiller bold med Øst og Vest, gammelt og nyt, Gud og Djævelen, godt og ondt, indtil alle metafysiske kategorier $b_{r y}$ der sammen, og "kneppe-æde-drikke-skide-pisse-planet" tiltrækker sig (næsten) al opmærksomhed her, midt i den vestlige verden, hvor hele sceneriet (med Reeds ord i Yellow Back Radio BrokeDown) $\mathrm{li}_{\mathrm{g} n}$ er "et afsnit af helvede som er skåret af og flyttet ovenpå, Yellow Back Radio, hvor selv solen var bange for at vise rumpen..."75Ligesom hos Blake er med andre ord det evige helvede vågnet, og himlens storhedstid er definitivt forbi! 76 
Den moderne medievirkelighed (,,Yellow Back Radio") invaderes hele tiden af stemmer fra det underste land - og fra en fortid det er umuligt at undslippe!

\section{Noter}

1. Arthur 0. Lovejoy: The Great Chain of Being. A Study of the History of an Idea (New York: Harper \& Brothers, 1960), p. 49 (min overs.).

2. The Poetry and Prose of William Blake. Edited by David V. Erdman. Commentary by Harold Bloom (Garden City, New York: Doubleday \& Company, Fourth Printing, with Revisions, 1970), p. 71 (min overs.).

3. Mikhail Bakhtin: Problems of Dostoevsky's Poetics. Edited and Translated by Caryl Emerson. Introduction by Wayne C. Booth (Minneapolis: University of Minnesota Press, Second printing, 1985), pp. 116-17 (min overs.).

4. Ishmael Reed: The Freelance Pallbearers. An irreverent novel (London: Allison \& Busby, 1990), p. 150 (min overs.) (,I was hung by meathooks in the Emperor Franz Joseph Park").

5. Ishmael Reed: Shrovetide in Old New Orleans (New York: Atheneum, 1989), p. 11 (min overs.).

6. Ibid., p. 11 (min overs.).

7. Jf. Mikhail Bakhtin: Rabelais and His World (Cambridge, Massachusetts, and London, England: The M.I.T. Press, 1968), p. 222: „Mardi Gras is Shrove Tuesday. A carnivalesque atmosphere permeates the entire episode [dvs. Gargamelles nedkomst hos Rabelais]; it ties into one grotesque knot the slaughter, the dismemberment and disemboweling, bodily life, abundance, fat, the banquet, merry improprieties, and finally childbirth."

8. Ibid., p. 266 (min overs.).

9. Jf. Mikhail Bakhtin, Problems of Dostoevsky's Poetics, op. cit., p. 124, hvor Bakhtin i forbindelse med karnevallets verden-på-hovedet taler om "the joyful relativity of all structure and order, of all authority and all (hierarchical) position" (Bakhtins fremhævelse).

10. Jf. Norman 0 . Brown: Life Against Death. The Psychoanalytical Meaning of History (London: Sphere Books Ltd., Second impression 1960, Reprinted November 1970), pp. 163-81 („The Excremental Vision").

11. Ishmael Reed: The Freelance Pallbearers, op. cit., pp. 59-60 (min overs.).

12. Jf. Anker Gemzøe: „Dialogen og den tragiske farce - Michail Bachtins teoretiske arbejde". Oprindelig trykt i Poetik, N.1.1971. Genoptrykt 
in: Litteraturvidenskab. Antologi af artikler fra tidsskriftet Poetik 1970-72 (Roskilde: RUC boghandel og forlag, 1974), p. 130.

13. Ishmael Reed: The Freelance Pallbearers, op. cit., p. 1.

14. Ibid., p. 54 (min overs., Reeds frem.hævelse).

15. Jf. ibid., p. 57.

16. Jf. Sigmund Freud: „Character and Anal Erotism" (1908), genoptrykt i Ernest Bornemann (ed.): The Psychoanalysis of Money (New York: Urizen Books, 1976), pp. $76-77$ (min overs.): ,In reality, wherever archaic modes of thought have predominated or persist- in the ancient civilizations, in myths, fairy tales and superstitions, in unconscious thinking, in dreams and in neuroses - money is brought into the most intimate relationship to dirt [...] lndeed, even according to ancient Babylonian doctrine gold is 'the faeces of Heil'".

17. Jf. William Morris: News from Nowhere. Edited by James Redmond (London and Boston: Routledge \& Kegan Paul, Reprinted 1972), p. 18 (min overs.).

18. Jf. The Complete Works of Nathanael West (London: Secker \& Warburg, Reprinted and reissued 1968), p. 249 (min overs.).

19. Ishmael Reed: The Freelance Pallbearers, -op. cit., p. 100 (min overs.).

20. Ibid., p. 102 (min overs.) (,I could not believe it, the audience was applauding its own doom"). Denne passage minder en passant om et af Kierkegaards diapsalmata: „Det hændte paa et Theater, at der gik Ild i Coulisserne. Bajads kom for at underrette Publicum derom. Man troede, det var en Vittighed og applauderede; han gjentog det; man jublede endnu mere. Saaledes tænker jeg, at Verden vil gaae til Grunde under almindelig Jubel af vittige Hoveder, der troe, at det er en Witz." Søren Kierkegaard: Enten-Eller. Bind 1 (København: Gyldendal, 1965), p. 33.

21. Jf. Ishmael Reed: The Freelance Pallbearers, op. cit., pp. $93 \mathrm{ff}$.

22. Jf. Timothy Leary: The Politics of Ecstasy (New York: G.P. Putnam's Sons, 1968), pp. $222 \mathrm{ff,Si} \mathrm{kapitlet} \mathrm{"Start} \mathrm{Your} \mathrm{Own} \mathrm{Religion").} \mathrm{Jf.} \mathrm{specielt}$ pp. 223 ff., hvor mottoet: „Drop Out. Turn On. Tune In" ekspliciteres.

23. Jf. Ishmael Reed: The Freelance Pallbearers, op. cit., p. 5 (min overs.). Einar Pihl Helleland, Engelsk Institut, Århus Universitet, har gjort mig opmærksom på denne reference til Timothy Leary hos Reed.

24. Jf. Thomas Pynchon: „Entropy", in: 12 from the Sixties. Selected and introduced by Richard Kostelanetz (New York: Dell Publishing Co., Ine., Fourth printing, August 1972), p. 35 (min overs.).

25. Ronald Paulson: Representations of Revolution (1789-1820) (New Haven and London: Yale University Press, 1983), p. 237 (min overs.): "Undifferentiation is a characteristic shared by the gothic and the grotesque [...] both gothic and grotesque focus on the moment of estrangement, the transition between this world and that, when plant and human are in metamorphosis and in the process of growing indistinguishable." 
26. Ishmael Reed: The Freelance Pallbearers, op. cit., p. 16 (min overs.). Svigerfaderens $" \mathrm{~d}_{\mathrm{y}}$ iske" udseende passer begribeligvis meget dårligt sammen med hans helt igennem borgerligt-respektable (pensionist)status; men på et andet plan minder han os om middelalderens "vilde mænd"! 27. Ibid., p. 101.

28. Jf. Franz Kafka: Siimtliche Erziihlungen (Frankfurt am Main: Fischer Taschenbuch Verlag, 1983), p. 56 (min overs.). Jf. også min læsning af

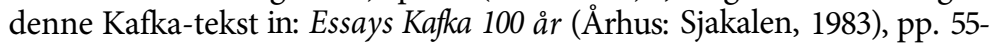
60.

29. Jf. Jurij Tynjanov: Die literarischen Kunstmitte/ und die Evolution in der Literatur (Frankfurt am Main: Suhrkamp Verlag, 1967), p. 140, om talende navne hos Gogol og Dostojevski.

30. Jf. The Complete Nonsense of Edward Lear. Edited and introduced by Holbrook Jackson (London: Faber and Faber Limited, Fourteenth impressionJuly 1977), pp. 225-28.

31. Ishmael Reed: The Freelance Pallbearers, op. cit., p. 152 (min overs.). 32. Jf. Roland Barthes: „Tekstanalyse af en fortælling af E.A. Poe", in: TidSkrift for moderne litteraturvidenskab, Nr. 3 (1984), p. 28.

33. Jf. Ishmael Reed: The Freelance Pallbearers, op. cit., P: 1 (min overs.).

34. Linda Hutcheon: A Poetics of Postmodernism. History, Theory, Fiction (New York and London: Routledge, reprinted 1989), p. 133 (min overs.). 35. Jf. Richard Brautigan: The Hawkline Monster. A Gothic Western (New York: Simon and Schuster, 1979) og William S. Boroughs: The Place of Dead Roads (New York: Holt, Rinehart a:nd Winston, First Gwl Book Edition, 1985).

,36. Ishmael Reed: Yellow Back Radio Broke-Down (New York: Atheneum, 1988), p. 24 (min overs.).

37. Ibid., p. 18 (min' overs.).

38. Ishmael Reed: The Freelance Pallbearers, op. cit., p. 50 (min overs.).

39. Ishmael Reed: Yellow Back Radio Broke-Down, op. cit., p. 17 (min overs.).

40. Jf. Julia Kristeva:.Powers of Horror. An Essay on Abjection. Translated by Leon S. Roudiez (New York: Columbia University Press, 1982), p. 20 (min overs.).

41. Ishmael Reed: Yellow Back Radio Broke-Down, op. cit., p. 174.

42. Ibid., p. 172 (min overs.). (, Sheath after sheath of strange lights flashed on their bodies and they melted slowly into a pile of goo").

43. Mircea Eliade: The Two and the One. Translated by J.M. Cohen (London: Harvill Press, 1965), p. 84 (min overs.).

44. Ishmael Reed: Yellow Back Radio Broke-Down, op. cit., p. 177 (min overs.).

45. Jf. C.G. Jung und Karl Kerenyi: Einfii.hrung in das Wesen der Mythologie. Das gottliche Kind. Das gottliche Miidchen (Zurich: Rhein-Verlag, 4. revidierte Auflage, 1951), passim. 
46. Ishmael Reed: Yellow Back Radio Broke-Down, op. cit., p. 9 (min overs.). 47. Robert Elliot Fox: Conscientious Sorcerers. The Black Postmodernist Fiction of LeRoi Jones/Amiri Baraka, Ishmael Reed, and Samuel R. Delany (New York, Westport, Connecticut, London: Greenwood Press, 1987), p. 6 (min overs.).

48. Ishmael Reed: Mumbo Jumbo (New York: Avon Books, First Bard Printing, March 1978, Second printing), p. 9 (min overs.).

49. Fredric Jameson: The Geopolitical Aesthetic. Cinema and Space in the World System (Bloomington and Indianapolis, London: Indiana University Press [and] BFI Publishing, 1992), p. 3 (min overs.).

50. Robert Elliot Fox, op. cit., pp. 52-53 (min overs.). Ifølge Ken Cooper i hans artikel "The Whiteness of the Bomb", trykt i Richard Dellamora (ed.): Postmodern Apocalypse. Theory and Cultural Practice at the End (Philadelphia: University of Pennsylvania Press, 1995), p. 89, er der tale om et ordspil, hvor der hentydes til the Ivy League (en gruppe ældre, højt estimerede amerikanske østkystuniversiteter, omfattende Brown, Columbia, Cornell, Harvard, Princeton, Yale, Dartmouth College og the University of Pennsylvania). Dvs. Gyldenlak-ordenen repræsenterer i denne forbindelse det akademiske establishment. (Cooper henviser i en note til Henry Louis Gates Jr.: The Signifying Monkey: A Theory of AfroAmerican Literary Criticism, New York: Oxford University Press, 1988, p. 225).

51. Om tempelherrernes storhed og fald jf. Norman Cohn: Europe's Inner Demons (Frogmore, St. Albans, Berts.: Paladin, 1976), specielt pp. $75 \mathrm{ff}$. Om den angivelige forbindelse mellem tempelherrer og frimurere jf. J.M. Roberts: The Mythology of the Secret Societies (Frogmore, St. Albans, Berts.: Paladin, 1974), specielt pp. 121-30.

52. Ishmael Reed: Mumbo Jumbo, op. cit., p. 216 (min overs.).

53. Jf. Leonora Carrington: The Hearing Trumpet (London and Henley: Routledge \& Kegan Paul, 1977), p. 157 (, This is how the Goddess [dvs. Venus] reclaimed her Holy Cup with an army of bees, wolves, six old women, a postman, a Chinaman, a poet, an atom-driven ark, and a werewoman. The strangest army, perhaps, ever seen on this planet").

54. Jf. Urnberto Beo: Foucaults pendul (København: Forum, 1989), p. 546.

55. Ishmael Reed: Mumbo Jumbo, op. cit., p. 50 (min overs.).

56. Jf. hertil f.eks. Wolfgang Kayser: Das Groteske in Malerei und Dichtung (Mii.nchen und Hamburg: Rowohlt, 1960), specielt p. 15.

57. Ishmael Reed: Mumbo Jumbo, op. cit., p. 248 (min overs.).

58. Ibid., p. 190 ( $\mathrm{min}$ overs.).

59. Ibid., p. 9 (min overs., Reeds fremhævelse).

60. Jf. Hugo Friedrich: Die Struktur der modernen Lyrik. Von Baudelaire bis zur Gegenwart (Hamburg: Rowohlt, 1964), p. 24 („leere Transzendenz") og p. 33 (, leere Idealitat") og passim. 
61. Jf. The Short Stories of Ernest Hemingway (New York: Charles Scribner's Sons, u.å.), p. 383,

62. Jf. The Novels of Dashiell Hammett (New York: Alfred A. Knopf, 1973), p. 430 („Gutman's knife-blade bit into the metal, turning back a thin curved shaving. The inside of the shaving, and the narrow plane its removal had left, had the soft grey sheen of lead...'It's a fake,' he said hoarsely").

63. Ishmael Reed: Mumbo Jumbo, op. cit., p. 213 (min overs.).

64. Ken Cooper: „The Whiteness of the Bomb", in: Richard Dellamora (ed.): Postmodern Apocalypse. Theory and Cultural Practice at the End (Philadelphia: University of Pennsylvania Press, 1995), p. 92 (min overs.).

65. Ishmael Reed: The Freelance Pallbearers, op. cit., p. 140 (min overs.).

66. Citeret i Ishmael Reed: The Last Days of Louisiana Red (New York: Atheneum, 1989), p. 3 (min overs.).

67. Ibid., p. 140 (min overs.).

68. Cab Calloways "Minnie the Moocher" begynder således: „Hey folks here's the story 'bout Minnie the Moocher / She was a low-down Hoochie Koocher / She was the roughest toughest frail / But Minnie had a heart as big as a whale..." Sangteksten citeres her fra http:// www.glue.umd.edu:80/hjeffrey/blues/text/minnie moocher.html. I Reeds roman har Minnie the Moocher mange træk tilfælles med den klassiske femme fatale.

69. Jf. plot-resumeet i forordet til Ishmael Reed: The Terrible Threes (New York: Atheneum, 1990), pp. 1-2.

70. Ishmael Reed: The Terrible Twos (London: Allison \& Busby, 1990), p. 4 (min overs.).

71. Ishmael Reed: Japanese by Spring (Harmondsworth, Middlesex: Penguin Books, 1996), p. 214 (min overs.).

72. Jf. Ishmael Reed: Shrovetide in Old New Orleans, op. dt., p. xx („Pteface").

73. Ishmael Reed: New and Collected Poems (New York: Atheneum, 1989), p. 7 (min overs.).

74. Ibid., p. 7.

75. Ishmael Reed: Yellow Back Radio Broke-Down, op. cit., p. 10 (min overs.).

76. Jf. William Blake: The Marriage of Heaven and Heil, in: The Poetry and Prose of William Blake. Edited by David V Erdman. Commentary by Harold Bloom (Garden City, New York: Doubleday \& Company, Foruth Printing, with Revisions, 1970), p. 34: , A sa new heaven is begun, and it is thirty-three years since its advent: the Eternal Hell revives..." 
